\title{
Rapid detection of bovine viral diarrhea virus using recombinase polymerase amplification combined with lateral flow dipstick assays in bulk milk
}

\author{
Peili Hou, Guimin Zhao, Hongmei Wang*, Chengqiang He, \\ and Hongbin $\mathrm{He}^{*}$
}

Key Laboratory of Animal Resistant Biology of Shandong, Ruminant Diseases Research Center, College of Life Sciences, Shandong Normal University, Jinan, China

HOU, P., G. ZHAO, H. WANG, C. HE, H. HE: Rapid detection of bovine viral diarrhea virus using recombinase polymerase amplification combined with lateral flow dipstick assays in bulk milk. Vet. arhiv 88, 627-642, 2018.

\section{ABSTRACT}

Bovine viral diarrhea virus (BVDV) is one of the most prevalent and economically important pathogens of ruminants, and leads to significant financial losses to the livestock industry worldwide. Development of rapid and accurate diagnostic methods is of great importance for the control and eradication of BVDV infection. The aim of this study was to develop a novel isothermal recombinase polymerase amplification (RPA) method combined with a lateral flow dipstick (LFD), for rapid detection of BVDV. RPA primers and a probe targeting the specific conserved 5'-UTR of BVDV genome were designed. The RPA amplification could be finished at a constant temperature of $38^{{ }^{0000} \mathrm{C}}$ for $15 \mathrm{~min}$, and the amplification product was easily visualized on a simple LFD within $5 \mathrm{~min}$. The detection limit of this assay was 20 copies per reaction, and there was no cross-reactivity with other bovine infectious viruses, such as infectious bovine rhinotracheitis virus (IBRV), bovine enterovirus (BEV), bovine coronavirus (BcoV), bovine parainfluenza virus type 3 (BPIV-3), bovine ephemeral fever virus (BEFV) and bovine respiratory syncytial virus (BRSV). The assay performance on bulk tank milk was also evaluated, and the sensitivity and accuracy of BVDV LFD RPA was compared with real-time RT-PCR. Of 284 pool or bulk tank milk samples, 51 were found to be positive by RPA assay, whereas 52 were positive by realtime RT-PCR. The coincidence rate between LFD RPA and real-time RT-PCR was 97.54\% (277/284).

Key words: bovine viral diarrhea virus (BVDV); recombinase polymerase amplification (RPA); lateral flow dipstick; bulk tank milk

\footnotetext{
${ }^{*}$ Corresponding authors:

Hongmei Wang, Hongbin He, College of Life Sciences, Shandong Normal University, No.88 East Wenhua Road, Jinan City, Shandong Province, China, Phone: +86 05318618 0201; E-mail: hongmeiwang@sdnu.edu.cn; hongbinhe@sdnu.edu.cn
} 


\section{P. Hou et al.: LFD RPA for rapid detection of BVDV}

\section{Introduction}

Bovine viral diarrhea virus (BVDV) is an economically important pathogen of widespread infectious diseases of cattle, pigs and other ruminants. BVDV infections are associated with multiple forms of clinical syndromes ranging from transiently detectable mild clinical symptoms to a fatal mucosal disease (BRODERSEN, 2014; LARSON, 2015). Moreover, persistently infected (PI) animals are the main source of virus transmission and spread the virus throughout their life, with typically asymptomatic or subclinical infections, which cause significant economic losses to the livestock industry worldwide (GROOMS et al., 2014; RODNING et al., 2012). Therefore, development of rapid and accurate diagnostic methods and removing positive animals from the herds is of primary importance for the control and eradication of BVDV infection.

BVDV belongs to the genus Pestivirus of the Flaviviridae family. It is a singlestranded, positive-sense RNA molecule consisting of the 5' untranslated region (5'-UTR), a single open reading frame (ORF) encoding structural proteins, and the $3^{\prime}$ untranslated region (3'-UTR). The $5^{\prime}$-UTR is most often targeted for molecular diagnostic tests and genetic typing due to its highly conserved region in the pestivus genome. Commonly, BVDV strains can be categorized into BVDV-1 and BVDV-2, and each genotype has been further divided into distinct subtypes (CIULLI et al., 2008; DENG et al., 2015). Most of all, while some BVDV-1 subtypes are currently widely distributed in cattle populations, there are also the sporadic reports of a certain number of BVDV-2 isolates in China (LIU et al., 2012; ZHU et al., 2016).

For large-scale epidemiological studies, antibody and nucleic acid detection of bulk tank milk (BTM) samples are used as an effective and inexpensive method to determine a herd's exposure to infectious agents (FODDAI et al., 2015; GONZALEZ et al., 2014). At present, BVDV antibody/antigens in bulk tank milk can be routinely detected using enzyme-linked immunosorbent assay (ELISA), conventional RT-PCR and real-time RT-PCR (DUBOVI, 2013; FODDAI et al., 2015; LANYON et al., 2014). However, the currently available diagnostic tests remain laboratory-based and require sophisticated instruments or commercial kits operated by specially trained personnel. Thus, the development of rapid and accurate bulk milk diagnostic methods is useful for identification of BVDV herd infection status.

Recombinase polymerase amplification (RPA) is a novel isothermal alternative to PCR, which targets and amplifies DNA from clinical samples with high sensitivity and specificity (PIEPENBURG et al., 2006). RPA is conducted independent of precise temperature control, and its amplification products can be detected by gel electrophoresis, probe-based fluorescence monitoring or lateral flow dipsticks (LFD) depending on the specific primers and/or probe configuration (PIEPENBURG et al., 2006; JAMES and MacDONALD 2015; DAHER et al., 2016). In particular, LFD is suitable for non- 
laboratory environments, as well as for use in resource limited fields, in virtue of its simplicity and portability (LIU et al., 2016). Recently, LFD-RPA assay has been widely applied for rapid visual detection of viruses, bacteria and parasites of veterinary importance (JAROENRAM and OWENS, 2014; KERSTING et al., 2014; LIU et al., 2017; TU et al., 2017; WU et al., 2017; YANG et al., 2016; YIN et al., 2017). Although fluorescence monitoring RPA technology has been used for detection of BVDV (AEBISCHER et al., 2014), the assay needs specialized fluorescent instruments and uses different labeled probes and primers from LFD RPA assay. However, there is no report about LFD RPA assay developed for detection of BVDV, evaluating its performance on clinical bulk tank milk samples.

In this study, we developed a rapid RPA method combined with a lateral flow dipstick (LFD) for simple, sensitive detection of BVDV, and evaluated its performance on clinical bulk tank milk samples.

\section{Materials and methods}

Viruses, cell and clinical specimens. Bovine viral diarrhea virus (BVDV)/NADL strain, infectious bovine rhinotracheitis virus (IBRV)/BarthaNu/67strain, and bovine parainfluenza virus type 3 (BPIV-3)/BN-1 strain were preserved in our laboratory. Other bovine virus strains for cross reactivity testing used in this study were provided by cloned cDNA: entire genome sequence of bovine enterovirus (BEV)/VG-5-27strain, bovine coronavirus (BcoV)/ENTstrain (Gene Bank No:NC_003045.1), bovine ephemeral fever virus (BEFV)/(Gene Bank No: NC_002526.1), bovine respiratory syncytial virus (BRSV)/A51908strain, respectively. 284 pool or bulk tank milk samples were collected from 22 dairy herds in China, with a scale ranging from 30 to 700 animals.

Isolation of DNA/RNA, cDNA synthesis. DNA/RNA of IBRV, BVDV and BPIV3 were extracted from $200 \mu \mathrm{L}$ of infected cell culture supernatant, using the viral DNA/ RNA extraction kit (TAKARA Co., Ltd., Japan) according to manufacturer's instructions. The DNA/RNA was eluted in $50 \mu \mathrm{L}$ of nuclease-free water, and then the extracted RNA was used as a template for cDNA synthesis using reverse transcription with random primers, according to the instructions for the RevertAid First Strand cDNA Synthesis Kit (Fermentas, Canada). All templates were stored at $-70^{\circ} \mathrm{C}$ until further use.

Generation of DNA standard. The BVDV 5'-UTR region fragment (300 bp) were synthesized by Jierui (Shanghai, China) and cloned into the pEASY-T3 vector, designated as 5'UTR-T3-RPA. The 5'UTR-T3-RPA standard DNA was measured using a Nanodrop ND-1000 spectrophotometer (Thermo Scientific, Dreieich, Germany). The DNA copy number was calculated by the equation: DNA cope number $=(\mathrm{M} \times 6.02 \times 1023 \times 10-9) /$ $(\mathrm{n} \times 660)$ (XIA et al., 2014), M: molecular weight, $\mathrm{n}$ : plasmid concentration measured at $260 \mathrm{~nm}$. DNA standard was stored at $-20^{\circ} \mathrm{C}$ until further use. 
Design of RPA primers and LF probe specific for BVDV. By alignment analysis of the conserved 5'-UTR region of BVDV representative reference strains, (as previously described by LUZZAGO et al. 2014), a series of primers and LF probes were designed according to the RPA instructions of TwistDx (TwistDx, Ltd., Cambridge, United Kingdom). Briefly, a length of $30 \mathrm{bp}$ to $35 \mathrm{bp}$ is recommended for RPA primers. The TwistAmp LF Probe oligonucleotide backbone includes a 5'-antigenic label FAM group, an internal abasic nucleotide analogue 'dSpacer' and a 3'-polymerase extension blocking group C3-spacer. One amplification primer opposing the TwistAmp LF Probe is labeled with biotin at its $5^{\prime}$ end, thus dual-labeled amplicon can be detected simultaneously on the LFD. Oligonucleotides of the primers and LF probes used in the study were synthesized by Sangon Biotech (Shanghai, China).

Optimization of laboratory based RPA assays. TwistAmp nfo kits were supplied as dry enzyme pellets in eight strips within vacuum-sealed pouches (TwistDx, Ltd., Cambridge, United Kingdom). The BVDV RPA was performed in a $50 \mu \mathrm{L}$ final reaction volume according to the instructions outlined in the Twist Amp nfo kit manual. The rehydration solution contained an optimized blend of DNA template and primers, and an LF probe. Each reconstituted reaction mixture contained $2 \mu \mathrm{L}$ DNA template, $2.1 \mu \mathrm{L}$ $(10 \mu \mathrm{M})$ primer, $0.6 \mu \mathrm{L}(10 \mu \mathrm{M})$ TwistAmp LF probe, and $29.5 \mu \mathrm{L}$ rehydration buffer. This mixture was then added directly to lyophilized RPA reagent pellet, followed by brief mixing, and then the reaction was initiated by adding $2.5 \mu \mathrm{L}$ of magnesium acetate (280 mM). The tubes were then incubated at $20{ }^{\circ} \mathrm{C}, 25{ }^{\circ} \mathrm{C}, 30^{\circ} \mathrm{C}, 35^{\circ} \mathrm{C}, 38{ }^{\circ} \mathrm{C}, 40{ }^{\circ} \mathrm{C}$, $42{ }^{\circ} \mathrm{C}$ or $50{ }^{\circ} \mathrm{C}$ in an incubator block for $4 \mathrm{~min}$. As recommended, the samples were blended top-down and bottom-up 6-8 times after 4 minutes' incubation, and additional incubation continued for $1 \mathrm{~min}, 6 \mathrm{~min}, 11 \mathrm{~min}, 16 \mathrm{~min}$, and $21 \mathrm{~min}$. In addition, in each run, the positive control template, supplied with the Twist Amp nfo kit (primers/probe and template) and a negative control template with (nuclease-free) water were included.

Lateral flow dipstick (LFD) assay. Milenia’s Genline Hybridetect-1 or Hybridetect-2 LFD duplexes labeled with anti-FAM gold conjugates and anti-Biotin antibodies from Milenia GmbH (Germany) were used in this study for detection of LFD-RPA amplified nucleic acids. $2 \mu \mathrm{L}$ of hybridisation products were mixed with $98 \mu \mathrm{L}$ of PBST $(1 \times$ phosphate buffered saline with $0.1 \%$ tween 20 ) running buffer. The LFD were then placed into the PBST dilution in a 96-well plate. The positive amplification product may be indicated by both test line and control line on the strip and visualized simultaneously within 5 min, and the negative control (no template) should generate a separate control line, whereas, the absence of a control line on the LFD indicates the strip did not work correctly.

Analytical of sensitivity, specificity and reproducibility of the assay. To determine the detection limits of this assay, ten-fold serial dilutions of the standard 5'UTR-T3RPA plasmid ranging from $2.0 \times 109$ to $2.0 \times 100$ copies per reaction were detected within 


\section{P. Hou et al.: LFD RPA for rapid detection of BVDV}

the same sample run. The operation steps were performed according to the section on optimization of laboratory based RPA assays.

The specificity of the assay was assessed using other bovine infectious pathogens. DNA of IBRV and cDNA of BVDV, BPIV-3 was prepared from cell culture supernatant, respectively. Clones of full genome of BEV, BcoV, BEFV and BRSV were supplied as templates in the LFD RPA reaction. Additionally, $2.0 \times 105$ copies per reaction of standard 5'UTR-T3-RPA plasmid of BVDV and BVDV-free samples were used as a positive control and a negative control respectively.

To evaluate the reproducibility of the LFD RPA assay, $2.0 \times 103$ copies per reaction, and $2.0 \times 101$ copies per reaction of standard 5'UTR-T3-RPA plasmid, used as a template and negative control (BVDV-free samples), were tested three times, respectively. The amplification product was shown on the strip visualized within $5 \mathrm{~min}$.

Bulk tank milk samples preparation. 284 pool or bulk tank milk samples were directly collected by the milk-truck driver from 22 dairy herds. In brief, the milk was agitated in the bulk tank for 5 min with sufficient mixing before collection, and then $5 \mathrm{~mL}$ of milk was pipetted into a sterilized centrifuge tube. Samples were stored on ice, transported under refrigeration to the laboratory immediately, and preserved at $4{ }^{\circ} \mathrm{C}$ until analysis. A $200 \mu \mathrm{L}$ milk sample was separated for RNA extraction using an RNA simple total RNA extraction kit (Tiangen Biotech, Beijing) according to the manufacturer's instructions. cDNA synthesis of the extracted RNA using random primers was prepared according to the instructions for the RevertAid First Strand cDNA Synthesis Kit (Fermentas, Canada). A volume of $2 \mu \mathrm{L}$ of cDNA extracted from each bulk tank milk specimen was used as a template in the RPA reactions.

SYBR Green I based real-time RT-PCR for amplification of BVDV. The qRT-PCR assay based on the SYBR Green I technology was performed for detection of BVDV with the primers targeting 5'-UTR. In brief, the oligonucleotides of the primers used in the qRT-PCR assay were as followed: BVD-F TGGTGAGTTGGTTGGATGGCTTAA, BVD-R CCCTATCAGGCTGTATTCGT. The reaction was carried out in a $25 \mu \mathrm{L}$ volume containing $12.5 \mu \mathrm{L}$ of SYBR Premix Ex Taq II (TAKARA, Japan), and $600 \mathrm{nM}$ of forward and reverse primers BVD-F and BVD-R, respectively. The thermal protocols were as follows: 1 cycle of $95^{\circ} \mathrm{C}$ for $30 \mathrm{~s}$, followed by 40 cycles of $95^{\circ} \mathrm{C}$ for $5 \mathrm{~s}$, annealing at 65 ${ }^{\circ} \mathrm{C}$ for $30 \mathrm{~s}$ and extension at $60{ }^{\circ} \mathrm{C}$ for $30 \mathrm{~s}$. The fluorescent signal was collected during the elongation step. In diagnostic real-time RT-PCR assays, the cycle threshold (Ct) cut-off value was set to 35 , meaning that $\mathrm{Ct}$ values $<35$ were considered positive and $\mathrm{Ct}$ values $\geq 35$ were considered negative. 


\section{Results}

Determination of LFD-RPA primers and probe. Four RPA primers and the corresponding LF probe targeting the 5'-UTR for detection of both BVDV genotypes were designed (Table 1) and employed for further validation in this study. The candidate primers/probe for the LFD-RPA assay were screened by performing TwistAmp nfo reactions and were preliminarily analyzed on the LFD, because the LFD-RPA reaction time is composed of the RPA constant-temperature amplification time and the LFD incubation time. The RPA amplification among those primer sets was conducted at 38 ${ }^{\circ} \mathrm{C}$ for $15 \mathrm{~min}$. The test line of the LFD results showed that the BV-4F/BV-4R/BV-4LF primers work effectively faster than other sets within 5 min (Fig. 1). Therefore, the BV4F/BV-4R/BV-4LF primer set was chosen for subsequent evaluation.

Table 1. The oligonucleotide sequences of primers and probes designed for screening in the study

\begin{tabular}{|c|c|c|}
\hline Primers & Oligonucleotide sequences ( $\left.5^{\prime}-3^{\prime}\right)$ & Sizes \\
\hline $\mathrm{BV}-1 \mathrm{~F}$ & 5'-AAATGTCCTGACAATGATGTACGGCTTCTGC-3' & \multirow{3}{*}{$188 \mathrm{bp}$} \\
\hline$B V-1 R$ & 5'-[Biotin]TTATCTTCTGAGGTTTGCCTGCTTCATGAAGAAT-3' & \\
\hline BV-1LF & $\begin{array}{l}\text { 5' - [FAM]GTCTGTGGGGATGATGGCT TCT TA ATAAC [d Spacer] } \\
\text { GAAAAAGGGTTAGGGCTGAAAT[C3-spacer]-3' }\end{array}$ & \\
\hline BV-2F & 5'-CAAGAGTTATCCAATACCCTGAAGCCAAGA-3' & \multirow{3}{*}{$158 \mathrm{bp}$} \\
\hline BV-2R & 5'-[Biotin]GAACGAGTCCCATTCCTTTCTCACTTTATC-3' & \\
\hline $\mathrm{BV}-2 \mathrm{LF}$ & $\begin{array}{l}\text { 5'-[FAM]ATA AAGTGAGAAAGGAATGGGACTCGTTC [dSpacer] } \\
\text { ATGAGCCAGTGGCCGTAA[C3-spacer]-3' }\end{array}$ & \\
\hline $\mathrm{BV}-3 \mathrm{~F}$ & 5'-CAAGAGTTATCCAATACCCTGAAGCCAAGA-3' & \multirow{3}{*}{$297 \mathrm{bp}$} \\
\hline BV-3R & 5'-[Biotin]GGTCGGTGATGGTGTCAATGAACTTGTGCCACTC-3' & \\
\hline BV-3LF & $\begin{array}{l}\text { 5'-[FAM]TGATAAAGTGAGAAAGGAATGGGACTCGTT[dSpacer] } \\
\text { AATGAGCCAGTGGCCGTA[C3-spacer]-3' }\end{array}$ & \\
\hline $\mathrm{BV}-4 \mathrm{~F}$ & 5'-CCTGAGTACAGGGTAGTCGTCAGTGGTTCGAC-3' & \multirow{3}{*}{$180 \mathrm{bp}$} \\
\hline BV-4R & 5'-[Biotin]CAATACAGTGGGCCTCTGCAGCACCCTATCAGGC-3' & \\
\hline BV-4LF & $\begin{array}{l}\text { 5'-[FAM]CTCGAGATGCCACGTGGACGAGGGCATGCCCA[dSpacer] } \\
\text { AGCACATCTTAACCTG[C3-spacer]-3' }\end{array}$ & \\
\hline
\end{tabular}

Note: F: forward primer; R: reverse primer; LF: probe; FAM: Carboxyfluorescein; dSpacer: a tetrahydrofuran residue; C3-spacer: 3'-block 


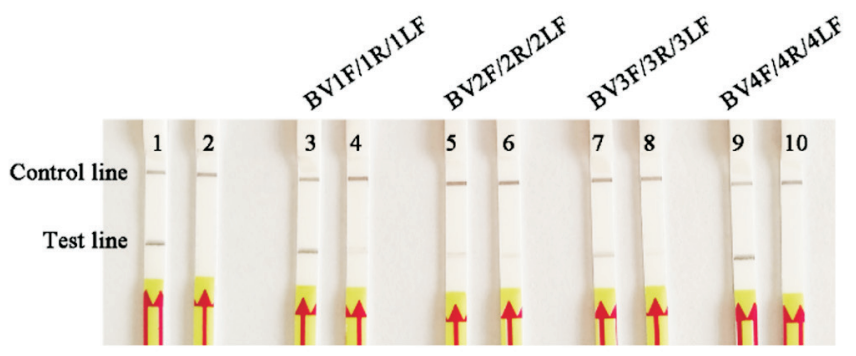

Fig. 1. Validating the designed primers/probe of BVDV LFD-RPA assay. Lateral-flow dipstick analysis of RPA products generated with designed primers/probes set. Lane 1: positive control

(supplied by Twist Amp nfo kit); Lane 2: negative control (supplied by Twist Amp nfo kit); Lane 3-4: BVDV amplicons performed with RPA primer pair BV1F/1R/1LF and corresponding negative control (DNase-free water), Lane 5-6: BV2F/2R/2LF and its negative control (DNasefree water); Lane 7-8: BV3F/3R/3LF and matches negative control (DNase-free water); Lane 9-10: BV4F/4R/4LF and respective negative control (DNase-free water). Samples were tested in triplicate with one reaction displayed in the figure for each triplicate.

Optimization of reaction temperature and incubation time. In searching for the optimal reaction conditions for this methodology, the results showed that the well amplified product was observed at a wide range of temperatures, from $30{ }^{\circ} \mathrm{C}$ to $42{ }^{\circ} \mathrm{C}$ (Fig. 2A), and a weaker visible test band was seen in reactions incubated at $20^{\circ} \mathrm{C}, 25$ ${ }^{\circ} \mathrm{C}$ and $50{ }^{\circ} \mathrm{C}$. To ensure maximum practical and handy use in the field, an incubation temperature of $38^{\circ} \mathrm{C}$ was selected for subsequent evaluation under different incubations. The results of reaction times demonstrated that the products could be effectively detected when the amplified time was 15 min or longer (Fig.2B). In order to keep this assay rapid, efficient and useful at the point of-care, the BVDV LFD-RPA assay was thus performed at $38^{\circ} \mathrm{C}$ for $15 \mathrm{~min}$.

Sensitivity, specificity and reproducibility of the RPA assay. The analytical sensitivity of the BVDV assays developed was determined using 10-fold serial dilutions of the standard G-T3-RPA plasmid, ranging from $2.0 \times 109$ to $2.0 \times 100$ copies per reaction. The minimum virus detection limits of LFD-RPA were as low as $2.0 \times 101$ copies per reaction (Fig.3A). For comparison, all these ten-fold serially diluted templates were performed by real-time qPCR, with the amplification curve based on the CT values, and showed that there was also limited detection at $2.0 \times 101$ copies per reaction (Fig. 3B). Therefore, the sensitivity of our LFD-RPA assay was identical to the real-time qPCR.

The specificity of the assay was assessed using other bovine infectious pathogens, such as IBRV, BPIV-3, BEV, BcoV, BEFV and BRSV. As shown in Fig.4A, no crossreactions were observed on the dipstick within 5 min, indicating that the selected primers/ 
probe were specific for BVDV detection. The reproducibility of the assay was tested with the standard plasmid and negative controls in 3 replicates. The results of the same templates showed the similar findings (Fig. 4B), demonstrating that this method is feasible with stability and repeatability.
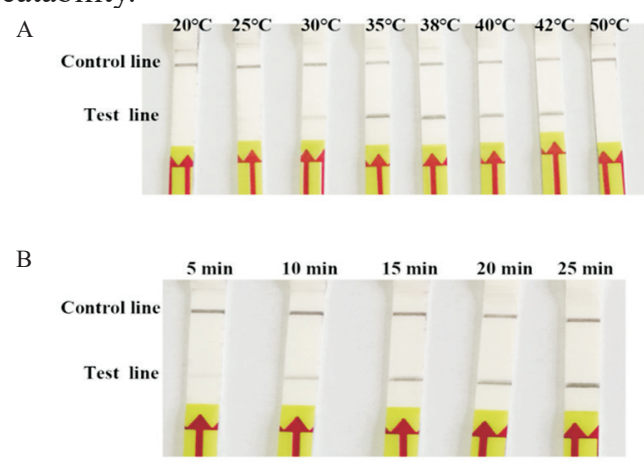

Fig. 2. Determination of reaction temperature and time. (A) The LFD-RPA works effectively at a broad range of constant reaction temperatures. (B) The LFD-RPA amplification can be visible on the LFD at $15 \mathrm{~min}$ or longer.

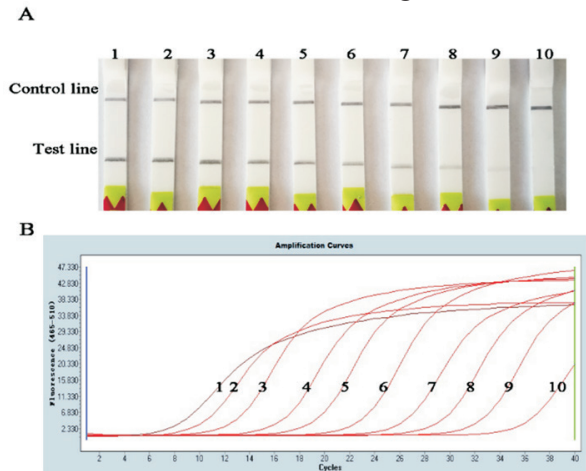

Fig. 3. Comparison of the sensitivities of the LFD-RPA and real-time RCR assay. (A) Molecular sensitivity of RPA. Templates of lane 1 to 10 in these reactions extracted from ten-fold serially diluted standard plasmid ranging from $2.0 \times 109$ to $2.0 \times 100$ copies per reaction. Samples were tested in triplicate with one reaction displayed in the figure for each triplicate. (B) Analytical sensitivity of real-time qPCR. Serial dilutions of BVDV standard plasmid were used to analyze the sensitivity of real-time qPCR with the same amount of template of RPA.

Performance of LFD-RPA on bulk milk. The LFD-RPA assay for the detection of BVDV was evaluated by performance of the assay on 284 bulk tank milk samples. The performance of the LFD-RPA assay was compared to that of the conventional RT-PCR and qRT-PCR assays. 
A

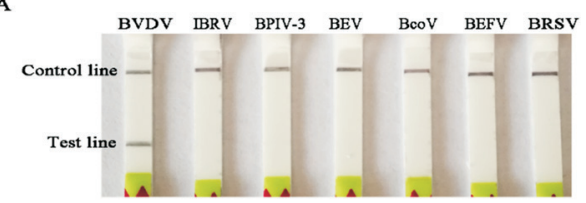

B

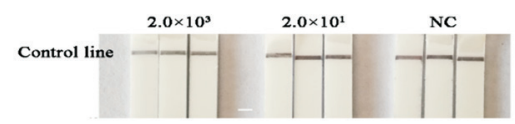

Fig. 4. Specificity of the LFD-RPA assay. (A) The specificity of the BVDV LFD-RPA assay. Lanes 1: BVDV; Lane 2: negative control (DNase-free water); Lanes 3 to 7: IBRV, BPIV-3, BEV, $\mathrm{BcoV}, \mathrm{BEFV}$, respectively. Samples were tested in triplicate with one reaction displayed in figure for each triplicate. B) Repeatability of limits detection. The sensitivity of the assay using BVDV templates extracted from $2.0 \times 103$ and $2.0 \times 101$ copies per reaction and negative control (DNasefree water) were also evaluated in 3 replicates, respectively. NC represents negative control.

The results of those assays showed that out of the 284 samples, a total of 24 bulk milk specimens tested positive by conventional RT-PCR, while in the performance of the BVDV RT-RPA in comparison to the qRT-PCR assay there were no significant differences since 51 specimens were found positive by BVDV RPA nucleic acid amplification assays on LFD within $5 \mathrm{~min}$, and 52 specimens were positive with the $\mathrm{Ct}$ values below 35 using the real-time RT-PCR assay. Therefore, the positive rates detected by conventional RTPCR, LFD-RPA, and real-time qPCR were 8.45\% (24/284), 17.96\% (51/284), 18.31\% (52/284), respectively. This particular LFD-RPA therefore was highly sensitive compared with the conventional RT-PCR, and was in good agreement with real-time RT-qPCR. In addition, the results indicate that the BVDV LFD-RPA might be suitable for detection of BVDV in bulk milk.

\section{Discussion}

BVDV is considered one of the most important pathogens of cattle, and contributes significantly to health-related economic losses in the cattle industry worldwide. To date, investigation of BVDV diversity has indicated that at least 18 potential subtypes (1a to 1t) have been described within BVDV-1, and of those subtypes, BVDV 1a, 1b, 1c, 1d, $1 \mathrm{~m}, 1 \mathrm{o}, 1 \mathrm{p}$, and $1 \mathrm{q}$ are currently predominant in the cattle population in China (DENG et al., 2015; XUE et al., 2010; ZHONG et al., 2011), and there is still a sporadic presence of a limited number of BVDV-2 isolates(LIU et al., 2012; WANG et al., 2014; ZHU et al., 2009). Therefore, establishing rapid detection methods, especially for both BVDV strains circulating in China, is the aim of BVD control projects. 
A crucial step of RPA is to identify the appropriate primers and probes. However, unlike PCR-based nucleotide amplification assays, it should be noted that the primer and probe set of RPA is much more stringent as it requires longer primers (30-35 bases) and probes (46-52 bases), leading to the potential for formation of secondary structures. Beyond that, there is no ideal design support software available for RPA. Furthermore, we also found that BVDV 5'-UTR partially overlaps with the region sequenced from reference isolates, which poses unique challenges for BVDV molecular detection. In this study, different primer and probe combinations were designed according to the dominant BVDV strains circulating in China (Table 1). The LFD-RPA system was first established by screening the effective primers and probes (Fig. 1), and then reaction temperature and incubation time were optimized for conditions with a wide temperature range $\left(30-42^{\circ} \mathrm{C}\right)$ (Fig. 2A, 2B). It indicated that the RPA reaction can be achieved with a simple heating device, even body heat (CRANNELL et al., 2014; LILLIS et al., 2014). In addition, the LFD-RPA assay can specifically amplify target DNA ranging from trace levels to detectable amounts of product in an isothermal format in less than 15 min, which was quicker than other methods including PCR, LAMP. With regard to analytical sensitivity, the RPA developed in this study showed a performance limit of detection of $2.0 \times 101$ copies per reaction equaled to RT-qPCR, which was much higher analytical sensitivity than the previously reported real-time RPA assay $(5.0 \times 104$ copies per reaction) (Fig. 3A, $3 \mathrm{~B})$. The study of specificity showed that the assay did not show test brand from other bovine infectious viruses or BVDV negative samples (Fig. 4A). It is worth mentioning that the high sensitivity and specificity of this assay supported the good use of goldlabeled anti-FAM and anti-Biotin antibodies to capture RPA product simultaneously. The reproducibility of the assay showed similar results (Fig. 4B), demonstrating that this method is stable.

As is well known, real time RPA and loop-mediated isothermal amplification (LAMP) for diagnosis of BVDV are innovative isothermal amplification nucleic acid tests (AEBISCHER et al., 2014). Nevertheless, LFD-RPA assay outperformed these methods in terms of simplicity, although LFD-RPA is not appropriate for quantitative analysis of nucleic acid. LFD-RPA assay generates testing results at body temperature (38) on the LFD with naked eye inspection, while the LAMP assay needs at least four primers and six binding sites and a high reactive temperature $\left(65^{\circ} \mathrm{C}\right)$, and real time RPA requires fluorescent instrumentation.

Previous studies have reported that bulk milk antibody testing is frequently used as a relatively quick and economical method for assessing herd BVDV exposure (GONZALEZ et al., 2014), and a number of diagnostic techniques, such as polymerase chain reaction, one-step single-tube RT-duplex PCR method, and virus isolation (VI) have proven to be in common use to evaluate lactating animals in a herd (BENDFELDT et al., 2005; KIM 


\section{P. Hou et al.: LFD RPA for rapid detection of BVDV}

and DUBOVI, 2003; RENSHAW et al., 2000). However, these methods have their own strengths and weaknesses in terms of low sensitivity, and they are time-consuming. In this study, we developed a rapid and highly sensitive LFD-RPA assay for the detection of BVDV in bulk milk. There was very good correlation between LFD- RPA and realtime RT-PCR (Table 2), which means that the molecular assay is suitable for detection in resource-limited settings. However, the BVDV LFD-RPA assay is not currently applied in the field because of the requirement of prepared BVDV genomes to make cDNA prior to performing the test, and further improvements and a substantial number of samples are required for better validation.

Table 2. Comparative performances of RT-PCR, LFD-RPA and Real-time RT-PCR assays for detection in bulk tank milk

\begin{tabular}{|c|c|c|c|c|c|c|c|c|}
\hline \multirow{2}{*}{$\begin{array}{c}\text { Herd } \\
\text { No. }\end{array}$} & \multirow{2}{*}{ Size } & \multirow{2}{*}{$\begin{array}{c}\text { Numbers of } \\
\text { bulk milk }\end{array}$} & \multicolumn{2}{|c|}{ LFD-RPA } & \multicolumn{2}{c|}{ RT-PCR } & \multicolumn{2}{c|}{ Real-time RT-PCR } \\
\cline { 4 - 9 } & Pos. & Neg. & Pos. & Neg. & Pos. & Neg. \\
\hline 1 & 700 & 18 & 6 & 12 & 4 & 14 & 6 & 12 \\
\hline 2 & 169 & 20 & 2 & 18 & 0 & 20 & 1 & 19 \\
\hline 3 & 368 & 11 & 3 & 8 & 0 & 11 & 3 & 8 \\
\hline 4 & 195 & 9 & 0 & 9 & 0 & 9 & 0 & 9 \\
\hline 5 & 95 & 13 & 2 & 11 & 1 & 12 & 2 & 11 \\
\hline 6 & 140 & 17 & 2 & 15 & 0 & 17 & 3 & 14 \\
\hline 7 & 102 & 11 & 3 & 8 & 1 & 10 & 3 & 8 \\
\hline 8 & 30 & 8 & 2 & 6 & 0 & 8 & 2 & 6 \\
\hline 9 & 207 & 16 & 5 & 11 & 4 & 12 & 6 & 10 \\
\hline 10 & 306 & 9 & 4 & 5 & 3 & 6 & 4 & 5 \\
\hline 11 & 148 & 19 & 3 & 16 & 2 & 17 & 3 & 16 \\
\hline 12 & 121 & 16 & 3 & 13 & 2 & 14 & 3 & 13 \\
\hline 13 & 209 & 10 & 1 & 9 & 0 & 10 & 2 & 8 \\
\hline 14 & 119 & 13 & 2 & 11 & 0 & 13 & 1 & 12 \\
\hline 15 & 68 & 15 & 1 & 14 & 0 & 15 & 1 & 14 \\
\hline 16 & 323 & 16 & 4 & 12 & 3 & 13 & 4 & 12 \\
\hline 17 & 102 & 11 & 2 & 9 & 1 & 10 & 2 & 9 \\
\hline 18 & 86 & 9 & 0 & 9 & 0 & 9 & 0 & 9 \\
\hline 19 & 377 & 19 & 2 & 17 & 0 & 19 & 2 & 17 \\
\hline 20 & 87 & 5 & 0 & 5 & 0 & 5 & 0 & 5 \\
\hline 21 & 670 & 8 & 1 & 7 & 1 & 7 & 1 & 7 \\
\hline 22 & 140 & 11 & 3 & 8 & 2 & 9 & 3 & 8 \\
\hline Total & 4762 & 284 & 51 & 233 & 24 & 260 & 52 & 232 \\
\hline
\end{tabular}




\section{P. Hou et al.: LFD RPA for rapid detection of BVDV}

\section{Conclusions}

A combination of RPA amplification with LFD detection was successfully developed for the rapid, sensitive and specific detection of BVDV in bulk milk. In addition, this methodology of LFD-RPA for BVDV may save much time in epidemiological surveillance and aid in identification of persistent BVDV infected individuals in beef and dairy farms.

\footnotetext{
$\overline{\text { Acknowledgements }}$

This work was partially supported by grants from a Taishan Scholar and Distinguished Experts (H. H.), the National Natural Science Fund of China (31502064, 31672556), Shandong Major Agricultural Application Technology Innovation Project (H.W), Primary Research \& Development Plan of Shandong Province (2015GNC113006, 2016GNC113006).
}

\section{References}

AEBISCHER, A., K. WERNIKE, B. HOFFMANN, M. BEER (2014): Rapid genome detection of Schmallenberg virus and bovine viral diarrhea virus by use of isothermal amplification methods and high-speed real-time reverse transcriptase PCR. J Clin Microbiol. 52,1883-1892. DOI:10.1128/JCM.00167-14.

BENDFELDT, S., U. FLEBBE, J. FRITZEMEIER, I. GREISER-WILKE, B. GRUMMER, L. HAAS, S. ORNBAN, E. PETERS, D. TIMM, V. MOENNING (2005): Analysis of bulk milk samples using polymerase chain reaction: an additional tool for bovine viral diarrhea monitoring. DTW. Dtsch. Tierarztl. Wochenschr. 112,130-135.

BRODERSEN, B. W. (2014): Bovine viral diarrhea virus infections: manifestations of infection and recent advances in understanding pathogenesis and control. Vet. Pathol. 51, 453-464.

DOI:10.1177/0300985813520250.

CiUlli, S., E. GAlletti, M. BATtilani, A. SCAGliarini, A. Gentile, L. MORGANTI, S. PROSPERI (2008): Genetic typing of bovine viral diarrhoea virus: evidence of an increasing number of variants in Italy. New Microbiol. 31, 263-271.

CRANNELL, Z. A., B. ROHRMAN, R. RICHARDS-KORTUM (2014): Equipment-free incubation of recombinase polymerase amplification reactions using body heat. PLoS One. 9, e112146. DOI:10.1371/journal.pone.0112146. eCollection 2014.

DAHER, R. K., G. STEWART, M. BOISSINOT, M. G. BERGERON (2016): Recombinase polymerase amplification for diagnostic applications. Clin. Chem. 62, 947-958.

DOI:10.1373/clinchem.2015.245829

DENG, M., S. JI, W. FEI, S. RAZA, C. HE, Y. CHEN, H. CHEN, A. GUO (2015): Prevalence study and genetic typing of bovine viral diarrhea virus (BVDV) in four bovine species in China. PLoS One. 10, e0121718.

DOI:10.1371/journal.pone.0121718. eCollection 2015

DUBOVI, E. J. ( 2013): Laboratory diagnosis of bovine viral diarrhea virus. Biologicals. 41, 8-13. DOI:10.1016/j.biologicals.2012.06.004 
FODDAI, A., C. ENOE, A. STOCKMARR, K. KROGH, A. UTTENTHAL (2015): Challenges for bovine viral diarrhoea virus antibody detection in bulk milk by antibody enzyme-linked immunosorbent assays due to changes in milk production levels. Acta Vet. Scand. 57, 32.

DOI:10.1186/s13028-015-0125-Z

GONZALEZ, A. M., I. ARNAIZ, C. EIRAS, F. CAMINO, M. L. SANJUAN, E. YUS, F. J. DIEGUEZ (2014): Monitoring the bulk milk antibody response to bovine viral diarrhea in dairy herds vaccinated with inactivated vaccines. J Dairy Sci. 97, 3684-3688.

DOI:10.3168/jds.2013-7851

GROOMS, D. L., K. V. BROCK, S. R. BOLIN, D. M. GROTELUESCHEN, V. S. CORTESE (2014): Effect of constant exposure to cattle persistently infected with bovine viral diarrhea virus on morbidity and mortality rates and performance of feedlot cattle. J. Am. Vet. Med. Assoc. 244, 212-224.

DOI:10.2460/javma.244.2.212

JAROENRAM, W., L. OWENS (2014): Recombinase polymerase amplification combined with a lateral flow dipstick for discriminating between infectious Penaeus stylirostris densovirus and virus-related sequences in shrimp genome. J. Virol. Methods 208, 144-151.

DOI:10.1016/j.jviromet.2014.08.006

JAMES, A., J. MacDONALD (2015): Recombinase polymerase amplification: Emergence as a critical molecular technology for rapid, low-resource diagnostics. Expert Rev. Mol. Diagn. 15, 1475-1489.

DOI: $10.1586 / 14737159.2015 .1090877$

KERSTING, S., V. RAUSCH, F. F. BIER, M. VON NICKISCH-ROSENEGK (2014): Rapid detection of Plasmodium falciparum with isothermal recombinase polymerase amplification and lateral flow analysis. Malar J. 13, 99.

DOI:10.1186/1475-2875-13-99

KIM, S. G., E. J. DUBOVI (2003): A novel simple one-step single-tube RT-duplex PCR method with an internal control for detection of bovine viral diarrhoea virus in bulk milk, blood, and follicular fluid samples. Biologicals 31, 103-106.

LANYON, S. R., F. I. HILL, M. P. REICHEL, J. BROWNLIE (2014): Bovine viral diarrhoea: pathogenesis and diagnosis. Vet. J. 199, 201-209.

DOI:10.1016/j.tvj1.2013.07.024

LARSON, R. L (2015): Bovine viral diarrhea virus-associated disease in feedlot cattle. Vet. Clin. North Am. Food Anim. Pract. 31, 367-380.

DOI:10.1016/j.cvfa.2015.05.007

LILlis, L., D. LEHMAN, M. C. SINGHAL, J. CANTERA, J. INGLETON, P. ABATRE, A. TOYAMA, O. IEPENBURG, M. PARKER, R. WOOD, J. VERBAUGH, D. S. BOYLE (2014): Non-instrumented incubation of a recombinase polymerase amplification assay for the rapid and sensitive detection of proviral HIV-1 DNA. PLoS One 9, e108189.

DOI:10.1371/journal.pone.0108189. 
LIU, H., Y. LI, M. GAO, K. WEN, Y. JIA, X. LIU, W. ZHANG, B. MA, J. WANG (2012): Complete genome sequence of a bovine viral diarrhea virus 2 from commercial fetal bovine serum. J. Virol. 86, 10233.

DOI:10.1128/JVI.01581-12.

LIU, H. B., Y. X. ZANG, X. J. DU, P. LI, S. WANG (2017): Development of an isothermal amplification-based assay for the rapid visual detection of Salmonella bacteria. J. Dairy Sci. 100, 7016-7025.

DOI:10.3168/jds.2017-12566

LIU, W., H. X. LIU, L. ZHANG, X. X. HOU, K. L. WAN, Q. HAO (2016): A novel isothermal assay of Borrelia burgdorferi by recombinase polymerase amplification with lateral flow detection. Int. J. Mol. Sci. 17, pii: E1250.

DOI:10.3390/ijms 17081250

LUZZAGO, C., S. LAUZI, E. BRANATI, M. IAMMARIOLI, A. ORENO, V. ANNELLA, L. MASOERO, E. CANELLI, A. UERCIO, C. CARUSO, M. ICCOZZI, G. M. DE MIA, P. L. CUTIS, G. EHENDER, S. PELETTO (2014): Extended genetic diversity of bovine viral diarrhea virus and frequency of genotypes and subtypes in cattle in Italy between 1995 and 2013. Biomed. Res. Int. 2014, Article ID 147145.

DOI: $10.1155 / 2014 / 147145$

PIEPENBURG, O., C. H. WILliAMS, D. L. STEMPLE, N. A. ARMES (2006): DNA detection using recombination proteins. PLoS Biol. 4, e204.

DOI:10.1371/journal.pbio.0040204

RENSHAW, R. W., R. RAY, E. J. DUBOVI (2000): Comparison of virus isolation and reverse transcription polymerase chain reaction assay for detection of bovine viral diarrhea virus in bulk milk tank samples. J. Vet. Diagn. Invest. 12, 184-186.

DOI: $10.1177 / 104063870001200219$

RODNING, S. P., M. D. GIVENS, M. S. MARLEY, Y. ZHANG, K. P. RIDDELL, P. K. GALIK, T. L. HATHCOCK, J. A. GARD, J. W. PREVATT, W. F. OWSLEY (2012): Reproductive and economic impact following controlled introduction of cattle persistently infected with bovine viral diarrhea virus into a naive group of heifers. Theriogenology 78, 1508-1516.

DOI:10.1016/j.theriogenology.2012.05.031

TU, P. A., J. S. SHIU, S. H. LEE, V. F. PANG, D. C. WANG, P. H. WANG (2017). Development of a recombinase polymerase amplification lateral flow dipstick (RPA-LFD) for the field diagnosis of caprine arthritis-encephalitis virus (CAEV) infection. J. Virol. Methods 243, 98-104.

DOI:10.1016/j.jviromet.2017.01.023

WANG, W., X. SHI, C. CHEN, H. WU (2014): Genetic characterization of a noncytopathic bovine viral diarrhea virus $2 \mathrm{~b}$ isolated from cattle in China. Virus Genes. 49, 339-341.

DOI:10.1007/s11262-014-1067-7 
WU, Y. D., M. J. XU, Q. Q. WANG, C. X. ZHOU, M. WANG, X. Q. ZHU, D. H. ZHOU (2017): Recombinase polymerase amplification (RPA) combined with lateral flow (LF) strip for detection of Toxoplasma gondii in the environment. Vet. Parasitol. 243, 199-203.

DOI:10.1016/j.vetpar.2017.06.026

XIA, X., Y. YU, M. WEIDMANN, Y. PAN, S. YAN, Y. WANG (2014): Rapid detection of shrimp white spot syndrome virus by real time, isothermal recombinase polymerase amplification assay. PLoS One 9, e104667.

DOI:10.1371/journal.pone.0104667

XUE, F., Y. M. ZHU, J. LI, L. C. ZHU, X. G. REN, J. K. FENG, H. F. SHI, Y. R GAO (2010): Genotyping of bovine viral diarrhea viruses from cattle in China between 2005 and 2008. Vet. Microbiol. 143, 379-383.

DOI:10.1016/j.vetmic.2009.11.010

YANG, Y., X. QIN, G. WANG, J. JIN, Y. SHANG, Z. ZHANG (2016): Development of an isothermoal amplification-based assay for rapid visual detection of an Orf virus. Virol. J. 13, 46.

DOI:10.1186/s12985-016-0502-X

YIN, F., J. LIU, A. LIU, Y. LI, J. LUO, G. GUAN, H. YIN (2017): Rapid diagnosis of Theileria annulata by recombinase polymerase amplification combined with a lateral flow strip (LFRPA) in epidemic regions. Vet. Parasitol. 237, 125-129.

DOI:10.1016/j.vetpar.2017.02.019

ZHONG, F., N. LI, X. HUANG, Y. GUO, H. CHEN, X. WANG, C. SHI, X. ZHANG (2011): Genetic typing and epidemiologic observation of bovine viral diarrhea virus in Western China. Virus Genes. 42, 204-207.

DOI:10.1007/s11262-010-0558-4

ZHU, L., H. LU, Y. CAO, X. GAI, C. GUO, Y. LIU, J. LIU, X. WANG (2016): Molecular Characterization of a Novel Bovine Viral Diarrhea Virus Isolate SD-15. PLoS One 11, e0165044.

DOI:10.1371/journal.pone.0165044

ZHU, L. Q., Y. Q. LIN, X. Y. DING, M. REN, J. TAO, J. Y. WANG, G. P. ZHANG, G. Q. ZHU, (2009): Genomic sequencing and characterization of a Chinese isolate of Bovine viral diarrhea virus 2. Acta Virol. 53, 197-202. 


\section{HOU, P., G. ZHAO, H. WANG, C. HE, H. HE: Brzo otkrivanje uzročnika virusnog proljeva goveda u mlijeku iz spremnika pomoću kombinacije metoda umnožene rekombinazne polimeraze i test-traka za ,lateral flow" analizu. Vet. arhiv 88, 627- 642, 2018.}

\section{SAŽETAK}

Uzročnik virusnog proljeva goveda (BVDV) jedan je od najčešćih i ekonomski važnih patogena preživača koji uzrokuje znatne financijske gubitke $u$ stočarskoj industriji širom svijeta. Razvoj brzih $i$ točnih dijagnostičkih metoda iznimno je važan za kontrolu i iskorjenjivanje zaraze BVDV-om. Cilj ovog istraživanja bio je razviti novu metodu za brzo otkrivanje BVDV-a baziranu na kombinaciji metoda umnožene rekombinazne polimeraze i test-traka za „lateral flow" analizu. Oblikovane su početnice i probe za umnažanje rekombinazne polimeraze usmjerene na specifični konzervirani 5'-UTR u genomu BVDV-a. Umnažanje se moglo završiti pri konstantnoj temperaturi od $38{ }^{\circ} \mathrm{C}$ tijekom 15 minuta i produkt umnažanja je lako vizualiziran na jednostavnoj test-traci za „lateral flow“ analizu unutar 5 minuta. Test je ograničen na 20 kopija po reakciji, pri čemu nije bilo križne reaktivnosti s drugim goveđim zaraznim virusima kao što su infektivni rinotraheitis virusa goveda (IBRV), goveđi enterovirus (BEV), goveđi koronavirus $(\mathrm{BcoV})$, virus goveđe parainfluence tipa 3 (BPIV-3), virus gljivične ephemeralne groznice (BEFV) i goveđi respiratorni sincicijski virus (BRSV). Učinkovitost kombinacije navedenih metoda istražena je i s obzirom na usporedbu osjetljivosti odnosno točnosti koja se dobiva uporabom RT-PCR metode. Od 284 skupna uzorka mlijeka iz spremnika, kombinacijom metoda umnožene rekombinazne polimeraze i test-traka za „lateral flow“ analizu utvrđen je 51 pozitivan uzorak, a RT-PCR 52 pozitivna uzorka. Stopa podudarnosti između navedenih metoda bila je 97,54\% (277/284).

Ključne riječi: uzročnik virusnog proljeva goveda (BVDV), umnažanje rekombinazne polimeraze, testtraka za „lateral flow“ analizu, mlijeko iz spremnika 